\title{
77 editorial
}

\section{an introduction to the issue from the Feminist Review Collective}

People are on the move across the globe, seeking labour elsewhere. While some 'jog-trot' across borders (Balibar, 2002: 83), and others negotiate the ever changing legal remit of border controls, a significant number risk their lives to get to those parts of the world where ( $a$ ) the bread is buttered and (b) their labour is needed. This special issue of Feminist Review brings the following contributions edited by the collective to sit alongside those brought to us by the guest editors Parvati Raghuram and Eleonore Kofman.

The demand for immaterial labour in the form of care work is increasingly met by women who travel across the world only to be positioned in less favourable conditions of employment from the 'locals'. The stratification of reproductive labour is inflected by class in conjunction with 'race' and nation. The points of intersection are however in no way configured in predictable patterns. In 'Contextual Politics of Difference in Transnational Care: the Rhetoric of Filipina Domestics' Employers in Taiwan' Shu-ju Ada Cheng pays attention to how Taiwanese employers discursively construct the otherness of Filipina domestics, many of whom are highly educated. She alerts us to how difference is localized in a transnational system of care that naturalizes the otherness of foreign domestics. Identity construction is in this discussion an interminable part of labour relations.

Sabine Hess and Annette Puckhaber insist on the importance of a transnational analyses of the similar and differing relations of power in care work. Using multi-sited ethnography in the movement, back and forth, of au pairs across Europe and the United States, they draw our attention to conflicting expectations. While au pairs see themselves as participants in cultural exchange programs, the host families view them as labourers. Located between employment contract and being a member of the familial, they occupy and negotiate the complex terrain of being neither. So often they witness a lack of recognition and dignity in the intimacy of what is simultaneously their public and private domain. Layers of spatial separation that may mark them out in the 'home' however do not stop them from building collectivities and strategies of empowerment with other, similarly placed, au pairs.

Kaori Nagai reminds us of the long history of care work and the myriad distinctions that operate within and through it. This article takes a close look 
at how colonial distinctions enabled Florence Nightingale to establish herself as an authoritative female subject in the public domain. Kaori Nagai identifies how the Lady with the Lamp assumed the voice of imperial England by suppressing other competing female voices of care. The service of the Irish nuns in the Crimean War was erased as their presence threatened to cancel out Nightingale's aspiring (imperial) political femininity. The place of Ireland as a nation is crucial to the kind of subjectivity Nightingale constructed through her labour of medical intervention and strategies of care.

Today, the post-colonial continues to affect both the flow and the reception of care workers across the globe. In the Dialogue section, Colleen McNeil-Walsh insists that current frameworks for understanding the migration of nurses from South Africa to Britain need to go beyond descriptive models in order to locate experiences of de-skilling and inequality within the complex terrain of the postcolonial. In a commentary on her latest interactive art installation 'Ghosting', Roshini Kempadoo responds to how the long stretch of migrations that forged labour and land ownership relations in the Caribbean bear traces upon postcolonial subjectivities and material locations. Her work invites us to engage with this haunting presence in British history. Kempadoo helps us to think about how we may bring to light the complexity of the existence of those specific bodies that have remained invisible in the history of plantations.

Today, the labour of those who maintain the infrastructure of our homes, hotels, office complexes and shopping malls is erased. Hegemonic definitions of the rhythms that define those spatial sites smother their presence. Using an ethnographic approach, Hsiao-Hung Pai seeks to give public visibility to this labour. Precarious conditions of life mark the existence of those without papers who migrate to undertake care work as well as industrial and agricultural labour on flower farms, meat-packing factories and sea beds with cockles. Hsiao-Hung Pai worked in Britain alongside workers from China who produce the food and goods that we consume in our everyday lives. She provides a vivid view of the connections between immigration status and precarious working and living conditions. Her incisive observations make political intervention an absolute necessity.

How we may politically respond to the proximity of those bodies whose labour is unrecognized is a conversation attended to in the contributions on activism. How leadership is represented and embodied is opened up for questioning in an email roundtable discussion between members of NextGENDERation who analyse the place of gender politics in the European Social Forum. NextGENDERation is an autonomous European network, with international links, of young scholars in feminism. Organized by virtual and face-to-face discussions, it is an exploratory collective that is open to new figurations. In their discussion, they also bear witness to the lack of analysis of 'race' in the unreflexive reach to the subaltern female within certain sections of the feminist movement in Paris 2003. From Madrid Maggie Schmitt informs us of Precarias a la Deriva, an initiative between 
research and activism that arose from the feminist social centre La Eskalera Karakola. Working through the metropolitan circuits of feminized and ethnicized precarious work, one of their projects - the Laboratorio de Trabajadores - sets in motion an operative place/moment to come together without denying conflict. Media technologies are used to innovate political experimentation.

The moment of immigration is clearly also an instance of emigration. The conditions that impel movement are intermittently tied to post-colonial legacies, as well as the relentless drive towards the neo-liberalization of communist and socialist regimes in Asia, South America and Eastern Europe. In a project from Zagreb entitled 'Milk', Kristina Leko presents a multimedia initiative where the artist and the activist come together in a communication project with those whose precarious situation risks further pauperization in the politics of transnational political economies. The lack of work - as documented by the photographs of Meta Krese - coupled with acute imbalances in currencies make migration, however tortuous, a necessity.

No doubt there are differential gains and losses in the equations of labour migration. Differences of class and status at the points of emigration allow invitations to be sponsored for those who are deemed as being appropriately 'skilled'. Those who cannot access these legal contortions bring their labour to our homes, offices, hospitals, supermarkets and factories by even more precarious channels. Treated as pollution and danger, their situations are the waste product of our 'successful' societies that rely on ever-increasing global inequalities (Bauman, 2003). Then of course there are those who do not have the resources to migrate in the first place, illegally or legally.

How do we bear witness to the 'suffering' (Sayad, 2004) of the 'immigrant'? In the Story/poetry section Jamila Qureshi takes us to the troubled terrain of testimonies. Qureshi's performance defies domestication of the racialised or gendered subject.

\section{Nirmal Puwar and Helen Crowley}

\section{references}

Balibar, $\boldsymbol{\varepsilon}$. (2002) Politics and the Other Scene, London, New York: Verso.

Bauman, Z. (2003) Wasted Lives: Modernity and its Outcasts, Cambridge: Polity.

Sayad, A. (2004) The Suffering of the Immigrant, Cambridge: Polity.

doi: $10.1057 /$ palgrave.fr. 9400176 